\title{
Bat flies (Diptera: Nycteribiidae) from Mount Makiling, Luzon Island: New host and distribution records, with a checklist of species found in the Philippines
}

\author{
James D.V. Alvarez ${ }^{1^{*}}$, Ireneo L. Lit, Jr. ${ }^{1,2}$, Phillip A. Alviola ${ }^{1,2}$ \\ 1 Museum of Natural History, University of the Philippines Los Baños, College, Laguna, Philippines 4031 \\ 2 Institute of Biological Sciences, College of Arts and Sciences, University of the Philippines Los Baños, College, Laguna, Philippines 4031 \\ * Corresponding author. E-mail: jamesalvarez21@gmail.com
}

\begin{abstract}
Our survey in Mount Makiling Forest Reserve, Luzon Island, Philippines from April to May 2011 revealed new host records of bat fly species (Diptera: Nycteribiidae), including: Eucampsipoda philippinensis Ferris, Cyclopodia garrula Maa, C. horsfieldi de Mejeire, Phthiridium brachyacantha (Theodor) and Penicillidia acuminata Theodor. We also report C. garrula as a new record for Luzon Island. A checklist of the species known from the Philippines with the known distribution and bat host species was also provided.
\end{abstract}

Key words: Mount Makiling, Philippines, bat fly, Nycteribiidae, bats

Mount Makiling Forest Reserve (MMFR) is situated at $14^{\circ} 09^{\prime}$ $\mathrm{N}, 121^{\circ} 11^{\prime}$ E (Mallari et al. 2001), $65 \mathrm{~km}$ southeast of Manila in the province of Laguna on the central part of Luzon Island and is surrounded by agricultural areas and human settlements. It remains to be one of the centers of biological diversity in the Philippines (Gonzalez 1997; Mallari et al. 2001) making it an extremely high conservation priority area (Ong et al. 2002) and one of the country's 32 key ecotourism sites (DOT-DENR 2002). It serves as a training field laboratory of the University of the Philippines Los Baños which gained exclusive jurisdiction, administration and complete control by virtue of Republic Act \#3523 and 6967 (Abraham et al. 2010). While most researches in MMFR are on bats (Sedlock 2002; Ingle 1992, 1993), information on ectoparasites associated with these bats is deemed inadequate.

Most bat ectoparasites belong to the lymph- or bloodsucking classes: Acari (mites and ticks) and Insecta (fleas, lice and parasitic flies). Among the most common are members of Nycteribiidae which are light brown, spider-like and wingless flies exclusively parasitic on bats (Dick and Patterson 2007; Bertola et al. 2005) although there are some accidental occurrences on birds (Maa 1975).

Ferris (1924a, 1924b, 1925a, 1925b), Maa (1962, 1966, 1968, 1975) and Theodor $(1955,1959,1963,1966,1967,1968)$ included descriptions of species from the Philippines. Apparently, none of these studies documented nycteribiids in Laguna province, specifically Mount Makiling. The most comprehensive review of Philippine nycteribiids was by Cuy $(1980,1981)$ wherein he reported at least nine species in Mount Makiling. Since the 1980s, only the study of Zabat and Eduardo (2011) has been published reporting on some nycteribiids.

This paper presents new host and island records of nycteribiids collected from four species of bats captured recently from MMFR. These bats were Cynopterus brachyotis (Muller), Ptenochirus jagori (Peters), Rousettus amplexicaudatus (Geoffroy) and Rhinolophus arcuatus Peters. Bats were captured through mist nets, V-nets and tunnel traps and preserved in $70 \%$ ethanol. Most of the host bats were released after extraction of the ectoparasites but a few were preserved as vouchers (see Appendix 1) as stipulated in the Gratuitous Permit (GP No. 207) from the Department of Environment and Natural Resources. All collected specimens were deposited at the UPLB Museum of Natural History (UPLB-MNH). All specimens examined were collected by JDV Alvarez and PA Alviola in April to May 2011 and labeled accordingly with the locality data as follows: Philippines: Luzon Is.: Mount Makiling.

\section{CYCLOPODIINAE}

Cyclopodia Kolenati

\section{Cyclopodia garrula Maa}

Cyclopodia garrula Maa 1968. Pacif. Ins. 10: 17.

GeOgRAPHICAL Distribution: Previously recorded only from Mindanao, it is the first time to document the species on the island of Luzon.

HOST RECORDS: The type specimens were collected only from Harpionycteris whiteheadi Thomas and currently recorded in Cynopterus brachyotis and Ptenochirus jagori (Maa 1968; Cuy 1980)

SPeCIMEN(s) EXAMINED: On Cynopterus brachyotis, 1 female (UPLBMNH-DIP-1530); on Ptenochirus jagori, 3 females (UPLBMNH-DIP-1527 to 1529).

\section{Cyclopodia horsfieldi de Mejeire}

Cyclopodia horsfieldi de Mejeire, 1899. Tijds. Ent. 42: 153.

GEOGRAPHICAL DISTRIBUTION: This species is widespread in 
various localities in the Philippines including Luzon, Mindoro, Busuanga, Culion, Palawan, Balabac, Leyte, Iloilo, Panay, Guimaras, Camiguin, Mindanao, Negros and Jolo (Ferris 1925; Theodor 1963; Cuy 1980, 1981). It is the first time to collect this species from Mount Makiling. It is also present in Indonesia, Cambodia, Malaysia, Thailand and Timor Leste (Cuy 1980).

HOST RECORDS: Initially identified as parasites of Pteropus Erxleben, Acerodon Jourdan, and Rousettus Gray species (Ferris 1925; Cuy 1980), new host records include Cynopterus brachyotis and Ptenochirus jagori.

Specimen(s) EXAMINED: On Cynopterus brachyotis, 1 male and 2 females (UPLBMNH-DIP-1531, 1536, 1540); on Ptenochirus jagori, 4 males and 4 females (UPLBMNH-DIP-1532 to 1535, 1537 to 1539,1541$)$.

\section{Eucampsipoda Kolenati}

\section{Eucampsipoda philippinensis Ferris}

Eucampsipoda philippinensis Ferris, 1924. Philipp. J. Sci. 24: 76.

GEOGRAPHICAL DISTRIBUTION: This species is probably endemic to the Philippines and is widely distributed in Luzon, Leyte, Negros, Mindanao (Ferris 1924; Theodor 1955; Cuy 1980), Palawan and Mindoro (Cuy 1981).

HOST RECORDS: Previously recorded from Eonycteris robusta Miller, Hipposideros diadema (Geoffroy) (Ferris 1924; Theodor 1955; Cuy 1980). New host record: Ptenochirus jagori.

Specimen(s) EXAMINed: On Ptenochirus jagori, 1 female (UPLBMNH-DIP-1542).

\section{Eucampsipoda sundaica Theodor}

Eucampsipoda sundaicum Theodor, 1955. Parasitology 45: 213.

GeOgRAPHICAL DISTRIBUtion: This species has been recorded in India, Myanmar, Laos, Cambodia, Thailand, Malaysia, Indonesia, and New Guinea. In the Philippines, it is known to occur in Luzon, Mindoro, Palawan, Leyte, Negros and Mindanao (Maa 1962; Cuy 1980, 1981).

HOST RECORDS: Hosts of this species include Eonycteris spelaea (Dobson) and Rousettus amplexicaudatus (Maa 1962; Cuy 1980).

SPECIMEN(s) EXAMINED: On Rousettus amplexicaudatus, 2 males and 2 females (UPLBMNH-DIP-1543 to 1546).

Leptocyclopodia Theodor

\section{Leptocyclopodia brevicula Maa}

Leptocyclopodia brevicula Maa, 1966. Pacif. Ins. 8: 677.

GeOgraphical Distribution: This Philippine endemic species is recorded only from Mindanao (Maa 1968) and Luzon (Cuy 1980).

Host RECORDS: This species parasitizes Ptenochirus jagori (Cuy 1980) which is endemic to the Philippines.

Specimen(s) exAmined: On Ptenochirus jagori, 7 males (UPLBMNH-DIP-1550 to 1557).

\section{Leptocyclopodia ferrarii mabuhai Maa}

Leptocyclopodia ferrarii mabuhai Maa, 1975. Pacif. Ins. 16: 474.

GeOgraphical Distribution: A Philippine endemic species widely distributed in Luzon, Leyte, Panay, Guimaras, Negros, Camiguin and Mindanao (Cuy 1980, 1981).

HOST RECORDS: Hosts of this species include Cynopterus brachyotis, Ptenochirus jagori, Haplonycteris fischeri Lawrence, Macroglossus lagochilus (=Macroglossus minimus Geoffroy), Eonycteris spelaea and Hipposideros diadema (Cuy 1980).

SPECIMEN(s) EXAMINED: On Cynopterus brachyotis, 3 males (UPLBMNH-DIP-1547 to 1549).

\section{Leptocyclopodia simulans (Theodor)}

Cyclopodia (Leptocyclopodia) simulans Theodor, 1959. Parasitology 49: 291.

Geographical distribution: This is another Philippine endemic species distributed in Luzon, Mindoro, Leyte, Bohol, Cebu, Negros, Camiguin and Mindanao (Cuy 1980).

Host RECORDs: This species is mainly on Ptenochirus jagori. Other hosts include Cynopterus brachyotis, Rousettus amplexicaudatus, Eonycteris robusta and Macroglossus lagochilus (=Macroglossus minimus) (Cuy 1980).

Specimen(s) eXAmined: On Ptenochirus jagori, 1 male (UPLBMNH-DIP-1572); on Cynopterus brachyotis, 7 males. (UPLBMNH-DIP-1565 to 1571).

\section{NYCTERIBIINAE}

Penicillidia Kolenati

\section{Penicillidia acuminata Theodor}

Penicillidia oceanica acuminata Theodor, 1963. Fieldiana (Zool.) 42: 174 .

GEOGRAPHICAL DISTRIBUtION: This species is known from Java and the Philippines (Luzon, Lubang, Tablas, Mindanao and Polillo) (Cuy 1980, 1981).

HOST RECORDS: This is a parasite of Miniopterus australis Tomes and M. schreibersii, Rhinolophus arcuatus, Tadarida luzonus (=Chaerephon plicatus (Buchanan)) and Emballonura alecto (Eydoux \& Gervais) (Cuy 1980) and newly recorded from Rousettus amplexicaudatus.

SPECIMEN(s) EXAMINED: On Rousettus amplexicaudatus, 1 male (UPLBMNH-DIP-1574).

\section{Phthiridium Hermann}

\section{Phthiridium brachyacantha (Theodor)}

Stylidia brachyacantha Theodor, 1963. Fieldiana (Zool.) 42: 164. Phthiridium brachyacantha: Maa, 1965. J. Med. Ent. 1: 381.

Geographical Distribution: This Philippine endemic species is recorded in Luzon and Mindanao (Cuy 1980, 1981).

HOST RECORDS: Initially identified only from Rhinolophus spp. (Cuy 1980), it is newly recorded in Ptenochirus jagori.

SPECIMEN(s) EXAMINED: On Rhinolophus arcuatus, 2 males and 4 females (UPLBMNH-DIP-1558 to 1563); on Ptenochirus jagori, 1 male (UPLBMNH-DIP-1564).

\section{Phthiridium mindanaense (Theodor)}

Stylidia mindanaensis Theodor, 1963. Fieldiana (Zool.) 42: 163. Phthiridium mindanaense: Maa, 1965. J. Med. Ent. 1: 381.

GeOgRAPHICAL DISTRIBUtion: Another Philippine endemic species recorded in Luzon and Mindanao (Cuy 1980, 1981).

HOST RECORDS: Initially identified only from unidentified Rhinolophus sp. (Cuy 1980), it is now recorded in Rhinolophus arcuatus.

SPECIMEN(s) EXAmined: On Rhinolophus arcuatus, 1 male (UPLBMNH-DIP-1573). 


\section{Nycteribiidae of the Philippines}

The following are the 20 species, one of them with two subspecies, of nycteribiid bat flies recorded in the Philippines. Geographical distribution and known host records together with the author of publications or accounts used as basis for locality data are also provided thereafter, except for those already included in the foregoing account of species from Mount Makiling, marked in the list below with an asterisk $\left(^{*}\right)$.

\section{Cyclopodinae}

\section{Cyclopodia garrula Maa*}

\section{Cyclopodia horsfieldi de Mejeire*}

Eucampsipoda inermis Theodor

GeOGRAPHICAL DISTRIBUtion: Myanmar, Thailand, Malaysia, Indonesia, Philippines (Luzon, Catanduanes, Mindoro, Busuanga, Palawan, Samal, Samar, Jolo, Mindanao, Negros) (Maa 1962; Cuy 1980, 1981)

HOST RECORDS: Rousettus amplexicaudatus, Eonycteris spelaea (Maa 1962; Cuy 1980)

\section{Eucampsipoda philippinensis Ferris*}

Eucampsipoda sundaica Theodor*

\section{Leptocyclopodia brevicula Maa*}

\section{Leptocyclopodia ferrarii mabuhai Maa*}

Leptocyclopodia ferrarii palawanensis (Theodor) GeOgraphicAL Distribution: Philippines (Busuanga, Culion, Palawan, Balabac) (Cuy 1981)

HOST RECORDS: Cynopterus brachyotis (Cuy 1980)

\section{Leptocyclopodia haplotes Maa}

GeOgRAPHICAL DISTRIBUtion: Philippines (Negros, Mindanao) (Cuy 1980, 1981)

HOST RECORDS: Haplonycteris fischeri, Cynopterus brachyotis, Ptenochirus jagori, Macroglossus lagochilus (=M. minimus) and Rousettus amplexicaudatus (Cuy 1980)

\section{Leptocyclopodia pilosipectus Maa}

GeOgraphical distribution: Philippines (Leyte, Negros, Camiguin, Mindanao) (Cuy 1980, 1981)

Host RECORDS: Harpionycteris whiteheadi, Haplonycteris fischeri, Ptenochirus jagori, Pteropus tablasi (=Pteropus pumilus Miller) (Maa, 1962, 1968; Cuy, 1980)

\section{Leptocyclopodia simulans (Theodor)*}

\section{NYCTERIBIINAE}

\section{Basilia majuscula (Edwards)}

GeographicAl Distribution: India, Sumatra, Philippines (Palawan) (Cuy 1980, 1981)

Host RECORDS: Pipistrellus imbricatus (=Pipistrellus javanicus (Gray)) (Cuy 1980)

\section{Nycteribia allotopa Speiser}

GeOgraPhicAl Distribution: China, Korea, Japan, Taiwan, India, Sri Lanka, Myanmar, Malaysia, Indonesia, Philippines (Luzon, Polillo, Tablas, Mindanao) (Cuy 1980, 1981)

Host RECORDS: Miniopterus schreibersii, M. australis, Tadarida luzonus (=Chaerephon plicatus) (Cuy 1980)

\section{Nycteribia allotopoides Theodor}

GeOgRAPHICAL Distribution: Myanmar, Philippines (Mindanao, Luzon, Polillo) (Cuy 1980, 1981)

Host RECORDs: Miniopterus australis, M. schreibersii (Cuy 1980)

\section{Nycteribia parvula Speiser}

GeOgRAPHICAL DISTRIBUtion: Afghanistan, Pakistan, India, Sri Lanka, Myanmar, Japan, Malaysia, Sumatra, Java, Amboina, Moluccas, New Guinea, Taiwan, Philippines (Luzon, Polillo, Tablas, Mindanao) (Cuy 1980, 1981)

HOST RECORDS: Miniopterus australis, M. schreibersii, Tadarida luzonus (=Chaerephon plicatus), Rhinolophus arcuatus (Ferris 1924; Maa 1962; Cuy 1980)

\section{Nycteribia parvuloides Theodor}

GeOgRAPHICAL Distribution: Nicobar Island, Malaysia, Philippines (Polillo, Mindanao) (Cuy 1980, 1981)

HOST RECORDS: Miniopterus australis, M. schreibersii, Hipposideros coronatus (Peters), Rousettus amplexicudatus and Eonycteris spelaea (Theodor 1963; Cuy 1980)

\section{Penicillidia acuminata Theodor*}

Penicillidia dufourii tainani Karaman

Geographical Distribution: Northern China, Japan, Taiwan, Philippines (Luzon) (Cuy 1980, 1981)

Host RECORDS: Rousettus amplexicaudatus (Maa 1962; Cuy 1980)

\section{Penicillidia oligacantha Theodor}

Geographical distribution: Philippines (Luzon, Tablas, Mindanao, Polillo) (Cuy 1980, 1981)

Host RECORDs: Miniopterus australis, M. schreibersii, Rousettus amplexicaudatus, Eonycteris spelaea (Cuy 1980)

Phthiridium brachyacantha (Theodor)*

\section{Phthiridium mindanaense (Theodor)*}

\section{ACKNOWLEDGMENTS}

We would like to express our gratitude to Edison A. Cosico (UPLB MNH), Eduardo G. Eres (UPLB MNH), Vicente Yngente, Wilson Bulalacao and Jayson Bulalacao for their assistance in the collection of bats and Dr. Leticia Afuang for her insights on the paper. Special thanks to Pusod, Inc. for procuring the necessary permit for the HEARST Biodiversity Expedition in Mount Makiling. The data presented in this paper are part of the corresponding author's B.Sc. thesis at the University of the Philippines Los Baños, entitled "Ectoparasite Diversity and Host-Parasite Association of Bats (Mammalia: Chiroptera) in Mount Makiling, Laguna, Philippines". 


\section{LITERATURE CITED}

Abraham E.R.G., J.C.T. Gonzalez, M.L. Castillo, I.L. Lit, Jr. and E.S. Fernando. 2010. Forest cover and biodiversity profile of the crater area of Mount Makiling, Luzon, Philippines. Asia Life Sciences Supplement 4: 49-82.

Bertola, P. B., C.C. Aires, S.E. Favorito, G. Graciolli, M. Amaku and R. Pinto-Darocha. 2005. Bat flies (Diptera: Streblidae, Nycteribiidae) parasitic on bats (Mammalia: Chiroptera) at Parque Estadual da Cantareira, São Paulo, Brazil: parasitism rates and host-parasite associations. Memoirs of Instituto Oswaldo Cruz 100(1): 25-32.

Cuy, L.S. 1980. Nycteribiidae (Diptera) of the Philippines. Kalikasan, The Philippine Journal of Biology 9(2-3): 145-168.

Cuy, L.S. 1981. Geographical distribution of Philippine Nycteribiidae and their hosts. Kalikasan, The Philippine Journal of Biology 10(2-3): 197-213.

Dick, C.W. and B.D. Patterson. 2007. Against all odds: Explaining high host specificity in dispersal-prone parasites. International Journal for Parasitology 37: 871-876 (doi: 10.1016/j.ijpara.2007.02.004).

DOT-DENR. 2002. National ecotourism strategy. Philippines: Department of Environment and Natural Resources. 119 pp.

Ferris, G.F. 1924a. Two Diptera Pupipara from Philippine bats. Philippine Journal of Science 24: 73-78.

Ferris, G.F. 1924b. Some Diptera Pupipara from the Philippine Islands. Philippine Journal of Science 25(4): 391-401.

Ferris, G.F. 1925a. Third report upon Diptera Pupipara from the Philippine Islands. Philippine Journal of Science 27: 413-421.

Ferris, G.F. 1925b. Fourth report upon Diptera Pupipara from the Philippine Islands. Philippine Journal of Science 28: 329-339.

Gonzalez, J.C.T. 1997. A Pictorial Guide to Philippine Endemic Forest Birds of Mount Makiling, Luzon Island, Philippines. Part I. Laguna: UPLB Museum of Natural History. 36 pp.

Ingle, N.R. 1992. The natural history of bats on Mount Makiling, Luzon Island, Philippines. Silliman Journal 36: 1-26.

Ingle, N.R. 1993. Vertical stratification of bats in a Philippine rainforest. Asia Life Sciences 2: 215-222.

Maa. T.C. 1962. Records and Descriptions of Nycteribiidae and Streblidae (Diptera). Pacific Insects 4(2): 417-436.

Maa, T.C. 1966. Partial revision of the Cyclopodiinae. Pacific Insects 8: 648-685.

Maa, T.C. 1968. Additions to the Cyclopodiinae Part I; (Diptera: Nycteribiidae). Pacific Insects 10(1): 1-23.

Maa, T.C. 1975. On new Diptera Pupipara from the Oriental Region. Pacific Insects 5: 40-48.
Mallari, N.A.D., B.R. Tabaranza, Jr. and M.J. Crosby. 2001. Key Conservation Sites in the Philippines: A Haribon Foundation and BirdLife International Directory of Important Bird Areas. Makati City: Bookmark, Inc. 485 pp.

Ong, P.S., L.E. Afuang, R.G. Rosell-Ambal (eds.). 2002. Philippine Biodiversity Conservation Priorities: A Second Iteration of the National Biodiversity Strategy and Action Plan. Quezon City: Department of Environment and Natural Resources-Protected Areas and Wildlife Bureau, Conservation International Philippines and University of the Philippines Center for Integrative and Development Studies. 113 pp.

Sedlock, J.L. 2002. Autecology and the conservation of insectivorous bats on Mount Makiling, Philippines. Silliman Journal 42: 163-201.

Theodor, O. 1955. On the genus Eucampsipoda Kol. and Dipseliopoda, n.g. Parasitology 45(1-2): 195-229 (doi: 10.1017/Soo31 182000027578).

Theodor, O. 1959. A revision of the genus Cyclopodia. Parasitology 49(1-2): 242-308 (doi: 10.1017/So031182000026858).

Theodor, O. 1963. Philippine Zoological Expedition 1946-1947. Philippine bat flies of the Family Nycteribiidae (Diptera, Pupipara). Fieldiana Zoology 42(11): 151-192.

Theodor, O. 1966. Diptera Pupipara collected by the Noona Dan Expedition in the Philippines and the Bismarck Islands. Journal of Medical Entomology 34: 535-536.

Theodor, O. 1968. New species and new records of Nycteribiidae from the Ethiopian, Oriental and Pacific Regions. Parasitology 58(2): 247-276 (doi: 10.1017/So031182000069328).

Authors' contribution statement: JDVA and PAA collected and identified the bats, JDVA and ILLJ identified the bat flies.

\author{
Received: May 2014 \\ Accepted: November 2014 \\ Editorial responsibility: Marco Gottschalk
}

APPENDIX 1. Summary of specimen vouchers of host bats collected from Mount Makiling and their respective museum catalog numbers. Cynopterus brachyotis: UPLBMNH-Z-NS-1174, 1175, 1178, 1182. Ptenochirus jagori: UPLBMNH-Z-NS-1203, 1208, 1214, 1225.

Rhinolophus arcuatus: UPLBMNH-Z-NS-1243-1245, 1255. Rousettus amplexicaudatus: UPLBMNH-Z-NS 1237-1238. 